


\section{Design of Smoke Control Systems for Areas of Refuge}

John H. Klote

Building and Fire Research Laboratory

Gaithersburg, MD 20899

March 1993

U.S. Department of Commerce

Ronald H. Brown, Secretary

National Institute of Standards and Technology

Raymond G. Kammer, Acting Director
General Services Administration

Dennis J. Fischer, Acting Administrator

Public Buildings Service

P. Gerald Thacker, Commissioner

Office of Real Property Management and Safety Washington, D.C. 20405 



\section{Table of Contents}

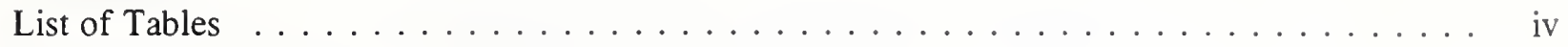

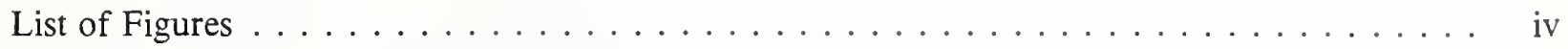

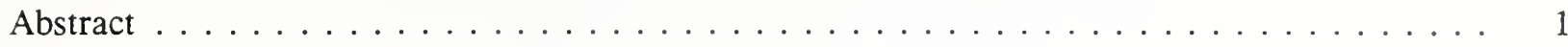

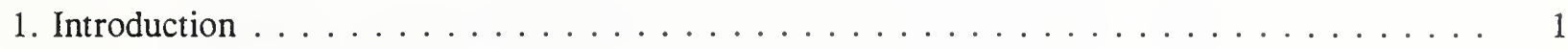

2. Design Pressure Differences ............................ 3

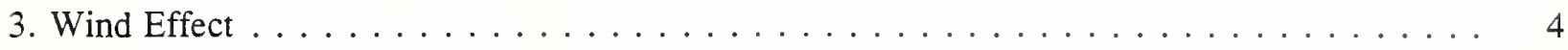

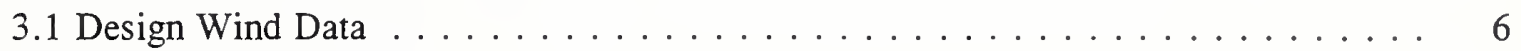

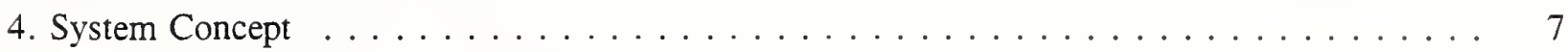

4.1 Pressure Fluctuations due to Open Doors . . . . . . . . . . . . . 7

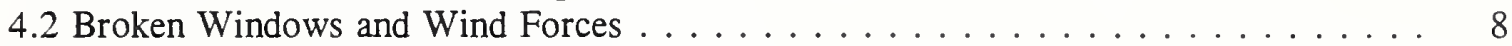

4.3 Applicability of Indirect Pressurization . . . . . . . . . . . . . 8

4.4 Systems to Deal with Fluctuations $\ldots \ldots \ldots \ldots \ldots \ldots \ldots$

5. Analysis of Smoke Control Systems . . . . . . . . . . . . . . . . . . . . 10

6. Example Application . . . . . . . . . . . . . . . . . . . . . . . 10

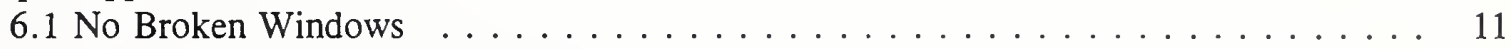

6.2 Broken Windows and No Wind . . . . . . . . . . . . . . . . . . 12

6.3 Broken Windows, Wind and Closed Doors . . . . . . . . . . . . . . . 12

6.4 Broken Windows, Wind and Opened Doors . . . . . . . . . . . . . . 13

6.5 Variable-Supply Air . . . . . . . . . . . . . . . . . . . . . . . 13

6.6 Adjustment for Building Leakage . . . . . . . . . . . . . . . . . . . . . 14

6.7 Adjustment for Building Leakage and Safety Factor . . . . . . . . . . . . . . 14

7. Effect of Fire Floor Temperature $\ldots \ldots \ldots \ldots \ldots \ldots \ldots \ldots \ldots$

8. Conclusions ................................ 16

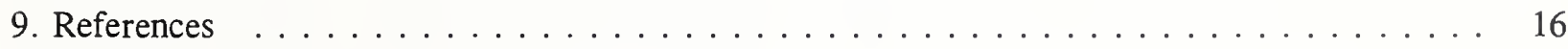




\section{List of Tables}

Table 1. Average pressure coefficients for walls of rectangular buildings . . . . . . . . 5

Table 2. Typical values of wind exponent and boundary layer height $\ldots \ldots \ldots \ldots \ldots$

Table 3. The effect of elevation on wind velocity and wind pressure . . . . . . . . . 18

Table 4. Design temperatures for analysis of example smoke control system . . . . . . . . 18

Table 5. Flow areas for analysis of example smoke control system . . . . . . . . . . . . 19

Table 6. Arrangement of doors and wind conditions for example analysis . . . . . . . . . . 20

Table 7. Computer-calculated pressure differences for smoke control example in SI units . . . 21

Table 8. Computer-calculated pressure differences for smoke control example in I-P units . . 22

\section{List of Figures}

Figure 1. Direct and indirect smoke control systems for areas of refuge . . . . . . . . 2

Figure 2. Gradient and boundary layer winds $\ldots \ldots \ldots \ldots \ldots \ldots \ldots \ldots \ldots \ldots$

Figure 3. Wind velocity profiles for different terrain . . . . . . . . . . . . . 6

Figure 4. Building of example analysis of smoke control system for an area of refuge $\ldots \ldots 10$ 


\section{DESIGN OF SMOKE CONTROL SYSTEMS FOR AREAS OF REFUGE}

\section{Abstract}

There is a rising concern for the safety of persons from fire who cannot travel building emergency exit routes in the same manner or as quickly as expected of able persons. One proposed solution for providing safety for persons with mobility limitations is the concept of areas of refuge (AOR) where they can "safely wait" until they can be assisted in leaving the building. This paper presents information about the design of smoke control systems to prevent smoke infiltration into an AOR. Pressure differences produced when windows break both with and without wind can be significant, and the design of a smoke control system for an AOR needs to address these pressure differences. The paper identifies that wind data specifically for the design of smoke control systems is needed. The pressure fluctuations due to opening and closing building doors during fire situations can also be significant, and the design of a smoke control system for an AOR needs to address these pressure fluctuations. An example analysis incorporating the pressure effects of broken windows, wind, and open doors illustrates the feasibility of designing smoke control systems for areas of refuge.

\section{Introduction}

There is a rising concern for the safety of persons from fire who cannot travel building emergency exit routes in the same manner or as quickly as expected of able persons. One proposed solution for providing safety for persons with mobility limitations is the provision of specific areas where they can "safely wait" until they can be assisted in leaving the building. To facilitate rescue, these areas generally are adjacent to elevators or stairs. For this paper, these areas are called areas of refuge (AOR), but they have also been referred to by a variety of names including areas of rescue assistance and staging areas. The concept of AOR has been promoted by a number of advocacy groups interested in persons with disabilities. Several regulatory documents such as the Life Safety Code (NFPA 1991) and the guidelines for the implementation of the Americans with Disabilities Act (Department of Justice, 1991) give descriptions of such areas.

The National Institute of Standards and Technology (NIST) has conducted a study funded by the General Services Administration (GSA) to evaluate the concept of AOR as a means of fire protection for persons with disabilities (Klote, Nelson, Deal and Levin 1992). The GSA staging area project consisted of field tests, threat analysis and a human behavior study of AOR in six office buildings. The threat analysis included the hazards inside AOR and hazards traveling to these areas for both sprinklered and unsprinklered buildings. For the design fires of the GSA study in unsprinklered buildings, all AOR would have needed smoke control systems to prevent lethal failure. For the buildings of the GSA study, it was concluded that the operation of a properly designed sprinkler system would eliminate the life threat to all occupants regardless of their individual abilities and would provide superior protection for people with disabilities as compared to staging areas. However, individual buildings will require individual engineering analysis. 


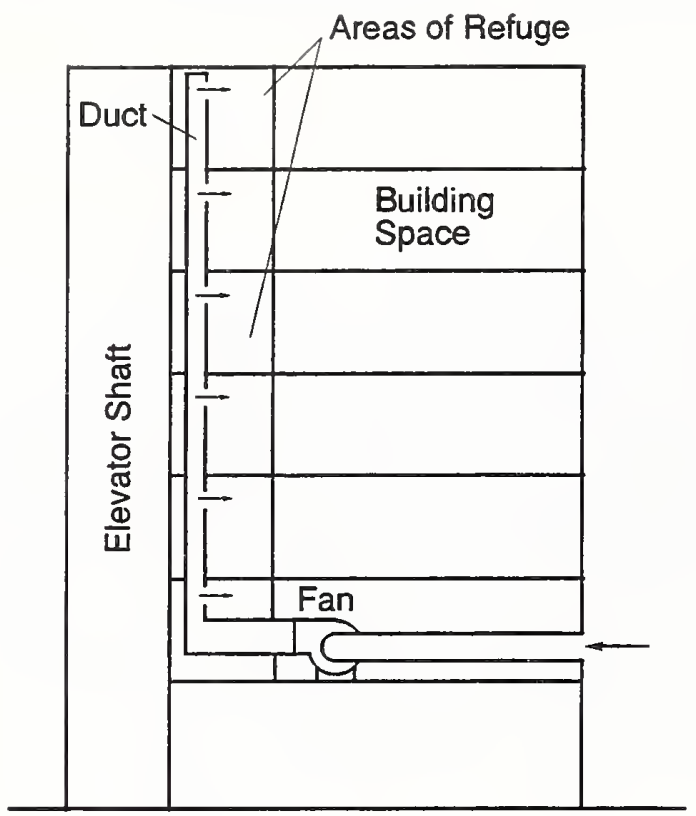

Direct Pressurization

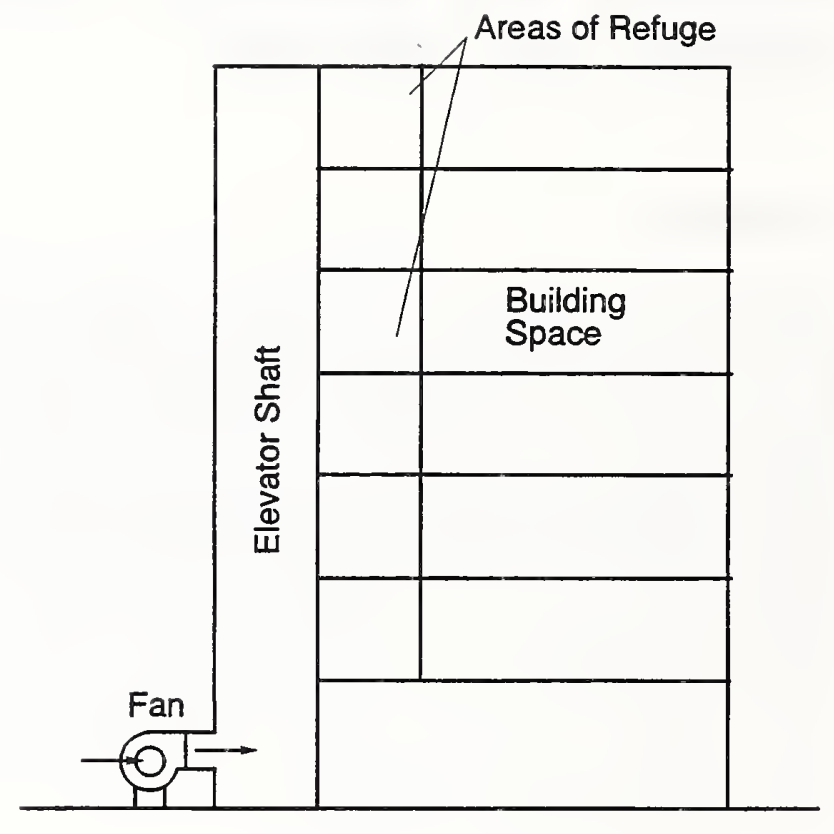

Indirect Pressurization

Figure 1. Direct and indirect smoke control systems for areas of refuge

This paper presents information about the design of smoke control systems to prevent smoke infiltration into an AOR with an example design analysis. The ASHRAE smoke control book (Klote and Milke 1992) presents design information for pressurized stairwells, pressurized elevators, zoned smoke control, and atrium smoke control. The systems presented in this paper are based on the same principles as these earlier systems, but the refuge area systems are unique in that they are intended specifically for persons with disabilities. Further, this paper addresses broken windows due to fire and the effects of wind on smoke control system performance. A method of calculating air infiltration due to wind was presented by Shaw and Tamura (1977). Aynsley (1989) developed a method of estimating the wind pressures at ventilation inlets and outlets. However, the method in this paper of dealing with wind and broken windows is unique in that it is specifically for smoke control applications.

Pressurization air can be supplied directly into each AOR or it can be supplied indirectly through an elevator shaft connected to the AOR as shown in figure 1. Theoretically, an indirect system could be supplied air through a stairwell, but it will be shown later that this usually is not appropriate. The direct system has the added expense of an air distribution duct and possibly a duct shaft including a corresponding loss of usable floor area. While the emphasis of this paper is on indirect pressurization, the principles presented in this paper are also applicable to both direct pressurization.

This paper deals with smoke control to prevent smoke infiltration into the AOR from a fire outside of the AOR. The smoke control system of this paper is not meant to deal with a fire inside the AOR. However for a fire in the AOR, the rest of the building can be thought of as providing refuge. For a fire in the AOR, shut down of the AOR smoke control system is one alternative. 


\section{Design Pressure Differences}

Upon activation of an AOR system, the AOR smoke control system is turned on, and the doors between the AOR and the building are automatically closed. The pressure difference across AOR doors must be limited to a value that does not result in excessive door-opening forces. The force to open a door can be calculated by a hydrostatic analysis of the moments on a door including the pressure difference across the door and the force of the door-closing mechanism (Klote and Milke 1992). The Life Safety Code (NFPA 1991) states that the force required to open any door that is a means of egress shall not exceed $133 \mathrm{~N}(30 \mathrm{lb})$. For a door-closing force of $45 \mathrm{~N}(10 \mathrm{lbs})$ on a $0.91 \mathrm{~m}$ (36 in) wide hinged door, a pressure difference of $85 \mathrm{~Pa}(0.34$ in $\mathrm{H} 2 \mathrm{O})$ results in a door-opening force of $133 \mathrm{~N}$ (30 lb). However, for an automatic opening and closing door, the maximum allowable pressure difference depends on the capabilities of the opening mechanism and not on the human force required to open the door.

Besides the maximum value of pressure difference, a system should also operate above a minimum value sufficient to prevent smoke infiltration into the AOR. The design approach is for this minimum value to incorporate the fire effect of buoyancy, and account for other driving forces discussed later in the analysis. The pressure difference due to buoyancy of hot fire gases between a fire compartment and its surroundings is expressed as

$$
\Delta p=K_{s} h\left(\frac{1}{T_{o}}-\frac{1}{T_{f}}\right)
$$

where:

$\Delta p=$ pressure difference, $\mathrm{Pa}$ (in $\mathrm{H} 2 \mathrm{O}$ )

$h=$ height above neutral plane, $\mathrm{m}(\mathrm{ft})$

$T_{o}=$ air temperature outside of fire compartment, $\mathrm{K}\left({ }^{\circ} \mathrm{R}\right)$

$T_{f}=$ temperature inside fire compartment, $\mathrm{K}\left({ }^{\circ} \mathrm{R}\right)$

$K_{s}=$ coefficient, $3460(7.64)$

For a fire compartment temperature of $930^{\circ} \mathrm{C}\left(1700^{\circ} \mathrm{F}\right)$, the pressure difference $1.82 \mathrm{~m}(6.0 \mathrm{ft})$ above the neutral plane is $16 \mathrm{~Pa}(0.065$ in $\mathrm{H} 2 \mathrm{O})$. NFPA $92 \mathrm{~A}$ (1988) suggests a minimum value of $25 \mathrm{~Pa}(0.10$ in $\mathrm{H} 2 \mathrm{O}$ ) for an unsprinklered building with a ceiling height of $2.74 \mathrm{~m}(9 \mathrm{ft})$. This considers the neutral plane at $1.82 \mathrm{~m}(6 \mathrm{ft})$ below the ceiling and allows a safety factor of $9 \mathrm{~Pa}(0.035$ in H2O). NFPA $92 \mathrm{~A}$ also suggests a minimum value of $12 \mathrm{~Pa}(0.05$ in $\mathrm{H} 2 \mathrm{O})$ for sprinklered buildings.

The minimum pressure difference discussed above applies to the fire floor, because this is where the fire puts its major stress on the smoke control system. Smoke control systems that require no information about the location of the fire floor must maintain at least the minimum pressure difference across the doors on all floors.

The above discussion of minimum pressure differences does not apply to variable-supply air systems that maintain a set pressure difference across the AOR doors on the fire floor. This set pressure difference is discussed later. The set pressure should be high enough so that the system is not adversely affected by transient pressures when adjusting to the opening or closing of doors. 


\section{Wind Effect}

The pressure that wind exerts on a surface can be expressed as

$$
P_{w}=\frac{1}{2} C_{w} \rho_{o} V^{2}
$$

where:

$P_{w}=$ wind pressure on a surface

$C_{w}=$ dimensionless pressure coefficient

$\rho_{o}=$ outside air density

$V=$ wind velocity

For an air density of $1.20 \mathrm{~kg} / \mathrm{m}^{3}\left(0.075 \mathrm{lb} / \mathrm{ft}^{3}\right)$ this relation becomes

$$
P_{w}=K_{w} C_{w} V^{2}
$$

where:

$P_{w}=$ wind pressure on a surface, $\mathrm{Pa}\left(\right.$ in $\left.\mathrm{H}_{2} \mathrm{O}\right)$

$C_{w}=$ dimensionless pressure coefficient

$V=$ wind velocity, $\mathrm{m} / \mathrm{s}(\mathrm{mph})$

$K_{w}=$ coefficient, $0.600\left(4.2 \times 10^{-4}\right)$

Generally, the pressure coefficient, $C_{w}$, is in the range of -0.8 to 0.8 , with positive values for windward walls and negative values for leeward walls. The pressure coefficient depends on building geometry and local wind obstructions, and the pressure coefficient varies locally over the wall surface. Values of pressure coefficient, $\overline{C_{w}}$, averaged over the wall area are listed in table 1 for rectangular buildings which are free of local obstructions.

The wind far above the earth is constant with elevation and is referred to as the gradient wind. From the ground to the gradient wind, the flow can be considered an atmospheric boundary layer where the velocity increases from zero at the ground to the speed of the gradient wind (figure 2). The flow in the boundary layer is effected by irregularities of the earth's surface and obstructions such as trees and buildings. Winds near buildings which have obstructions are non-uniform with vortices and secondary flows in various directions.

In the absence of obstructions, the relation between velocity and elevation is frequently expressed by the power law

$$
V=V_{o}\left(\frac{z}{z_{o}}\right)^{n}
$$


where:

$V=$ wind velocity, $\mathrm{m} / \mathrm{s}(\mathrm{fpm})$

$V_{o}=$ velocity at reference elevation, $\mathrm{m} / \mathrm{s}(\mathrm{fpm})$

$z=$ elevation of velocity, $\mathrm{V}, \mathrm{m}(\mathrm{ft})$

$z_{o}=$ reference elevation, $\mathrm{m}(\mathrm{ft})$

$n=$ wind exponent, dimensionless

Table 1. Average pressure coefficients for walls of rectangular buildings (Adapted from MacDonald [1975])

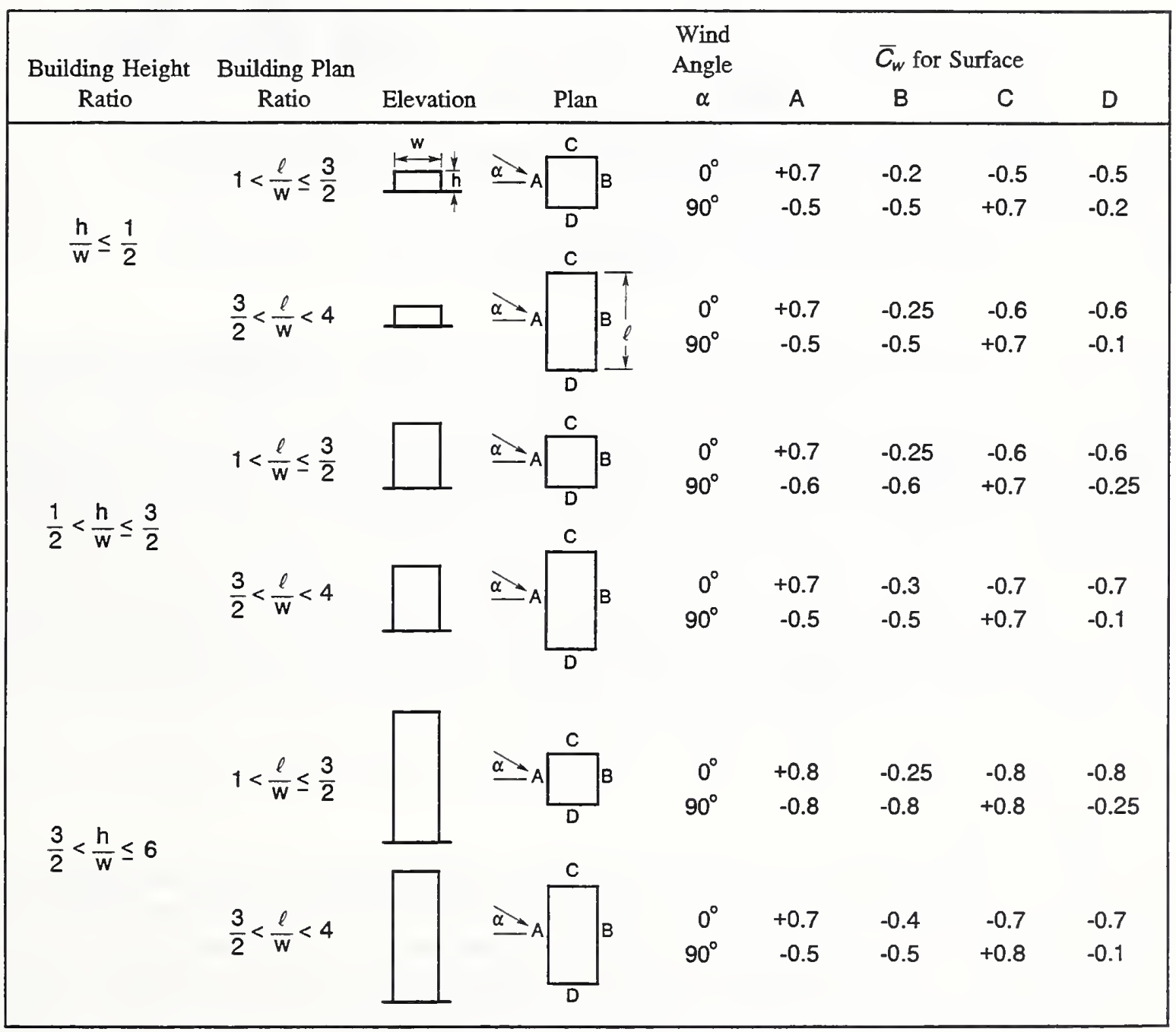

Note: $\mathrm{h}=$ height to eaves or parapit; $\ell=$ length (greater horizontal dimension of a building); $\mathrm{w}=$ width (lesser horizontal dimension of a building). 

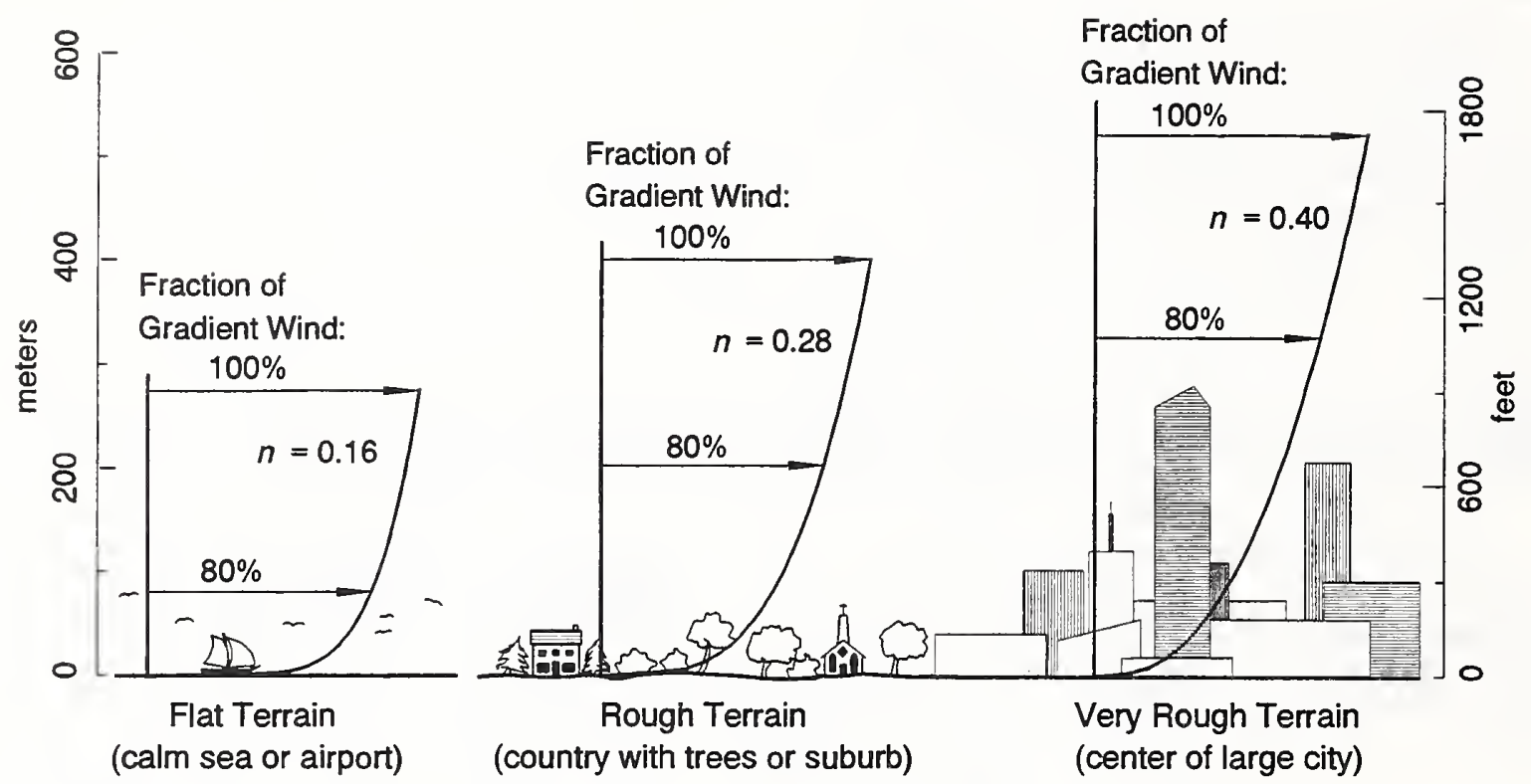

Figure 3. Wind velocity profiles for different terrain

There is some variation of recommended wind exponent and boundary layer thickness (Aynsley, 1989; Houghton and Carruthers, 1976; Kolousek et al., 1984; MacDonald, 1975; Sachs, 1978), but typical values are listed in table 2 and illustrated in figure 3. There is also a logarithmic relation for velocity in the boundary layer (Simiu and Scanlan, 1986) which is more complicated and possibly more accurate than the power law. However, the power law has been used extensively, and it seems that this simple relationship is appropriate for initial studies and analyses of wind effects on smoke control systems.

Wind data is recorded by airports and the weather service at heights, $z_{o}$, of about $10 \mathrm{~m}$ ( $33 \mathrm{ft}$ ) above the ground. Therefore, a reference elevation of $10 \mathrm{~m}(33 \mathrm{ft})$ will be used for the discussions and the example of this paper, unless otherwise stated. For buildings near obstructions to wind flow, specialized wind tunnel studies are needed to determine the wind pressures.

\subsection{Design Wind Data}

The Handbook of Fundamentals (ASHRAE 1989) lists prevailing wind directions and corresponding average wind speeds for numerous locations around the world. For most locations, these average velocities are in the range of 2 to $7 \mathrm{~m} / \mathrm{s}$ (4 to $16 \mathrm{mph}$ ). These average values are inappropriate for design, because there is a fifty percent probability that the wind speed will be greater during a fire emergency.

In structural engineering, wind design values are ones that statistically occur once during a long period ( 25 or 50 years). Generally, these velocities are in the range of 30 to $50 \mathrm{~m} / \mathrm{s}$ ( 70 to $110 \mathrm{mph}$ ). This approach is appropriate, because structures must function continuously for the life of the structure. However, smoke control systems need to operate only for a short time (about 15 to 90 minutes) over the 
Table 2. Typical values of wind exponent and boundary layer height

\begin{tabular}{|lccc|}
\hline & Wind Exponent & \multicolumn{2}{c|}{ Boundary Layer Height } \\
Terrain & $n$ & $\mathrm{~m}$ & $\mathrm{ft}$ \\
\hline Flat (calm sea or airport) & 0.16 & 275 & 900 \\
Rough (country with trees or suburb) & 0.28 & 400 & 1300 \\
Very Rough (center of large city) & 0.40 & 520 & 1700 \\
\hline
\end{tabular}

life of a building. The probability of having a simultaneous occurrence of a fire and the 25 or 50 year structural design wind is very small. It seems inappropriate to design a smoke control system for such a remote possibility.

What is needed is design data specifically for smoke control systems, and the ASHRAE Technical Committee (TC 5.6) Control of Fire and Smoke is developing a project to generate such data. Until smoke control design wind data is available, it is suggested that designers of such systems use wind speeds of two or three times the average ASHRAE value.

\section{System Concept}

A smoke control system for an AOR should be designed to pressurize the AOR to prevent smoke flow into the area. Generally, AOR will be connected to elevators or stairs to provide the capability for vertical transportation. Elevators of current design are not intended for fire evacuation and should not be used for fire evacuation. However, the idea of using elevators to evacuate persons with disabilities has gained considerable attention (Bazjanac 1974, Bazjanac 1977, Pauls 1977, Pauls, Gatfield and Juillet 1991, Gatfield 1991, Degenkolb 1991, and Fox 1991). The feasibility of using elevators for fire evacuation and design considerations of such elevator systems are discussed by Klote et al. (1992). Further, Klote and Milke (1992) provide design information about elevator smoke control systems based on joint US/Canadian research consisting of conceptual system studies, theoretical analysis and full scale fire experiments. Smoke control for AOR is similar in many respects to that for elevators, and the material in this paper draws upon that of Klote and Milke.

\subsection{Pressure Fluctuations due to Open Doors}

Smoke Control systems must be designed to maintain design pressure differences under the likely conditions of opened and closed doors. For pressurized elevators, Klote and Tamura (1986a) showed that opening a large flow path from the pressurized spaces to the outside can result in a significant loss in pressurization. For example, opening the elevator doors, AOR doors, and exterior doors resulted in a pressure drop from 0.13 in $\mathrm{H}_{2} \mathrm{O}(32 \mathrm{~Pa})$ to 0.03 in $\mathrm{H}_{2} \mathrm{O}(7 \mathrm{~Pa})$ for a system without features to resist pressure fluctuation. 
During a fire, it is expected that several exterior doors will be propped open, and stairwell doors will be opened and closed as people use the stairs. The AOR doors will open and close as people use the refuge areas. It is envisioned that refuge areas will have automatic doors ${ }^{1}$ or doors with automatic closers. However, refuge area doors can be inadvertently blocked and the mechanism can fail. It is anticipated that occupants will close any such opened doors to prevent being exposed to smoke.

Door may not be closed on some floors where there is no smoke danger or there are no people waiting in the refuge area. The probability of these doors being open depends on many factors including human behavior and the of the extent of acceptance testing and routine maintenance of doors and automatic door closers. The possibility of refuge area doors being open on floors away from the fire should be taken into account during the design. The example presented later presents one way of dealing with pressure fluctuations due to doors opening and closing.

\subsection{Broken Windows and Wind Forces}

Often, the elevated temperatures of fires result in broken windows. As indicated by Klote, Nelson, Deal and Levin (1992), fully involved room fires that have resulted in multiple fatalities have also resulted in broken windows in the fire compartment. A smoke control system should be capable of maintaining acceptable pressure differences with a fire compartment window broken under conditions of zero wind and a design wind. Further, the wind orientation is significant in that the wind may be blowing into the window or it may be sucking out through the window.

Table 3 lists velocities and wind pressures at elevations $35 \mathrm{~m}(115 \mathrm{ft})$ and $100 \mathrm{~m}(330 \mathrm{ft})$ for velocities

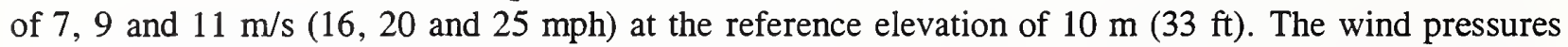
vary from 48 to $210 \mathrm{~Pa}\left(0.19\right.$ to 0.84 in $\left.\mathrm{H}_{2} \mathrm{O}\right)$. These pressures are significant in comparison with the design pressure differences discussed earlier, and the example presented later will show that designing for wind effects can be challenging.

\subsection{Applicability of Indirect Pressurization}

For indirect pressurization (figure 1), the pressure differences and flow areas connected to the AOR are related as

$$
\frac{\Delta P_{r b}}{\Delta P_{s r}}=\left(\frac{A_{r b}}{A_{s r}}\right)^{-2}
$$

where:

$\Delta P_{r b}=$ pressure difference from AOR to building space, $\mathrm{Pa}\left(\right.$ in $\left.\mathrm{H}_{2} \mathrm{O}\right)$

$\Delta P_{s r}=$ pressure difference from shaft to AOR, $\mathrm{Pa}\left(\right.$ in $\left.\mathrm{H}_{2} \mathrm{O}\right)$

$A_{r b}{ }^{S r}=$ flow area between the AOR and the building space, $\mathrm{m}^{2}\left(\mathrm{ft}^{2}\right)$

$A_{s r}=$ flow area between the shaft and the AOR, $\mathrm{m}^{2}\left(\mathrm{ft}^{2}\right)$

\footnotetext{
${ }^{1}$ The use of automatic doors for areas of refuge are addressed by Klote, Nelson, Deal and Levin (1992).
} 
To prevent smoke infiltration from the building into the AOR, the pressure difference, $\Delta P_{r b}$, from AOR to building space should be within the range of design values previously discussed. If the area ratio, $A_{r b} / A_{s r}$, is large, then the pressure ratio, $\Delta P_{r b} / \Delta P_{s r}$, is very small. For example if $A_{r b} / A_{s r}$ is 5 , then $\Delta P_{r b} / \Delta P_{s r}$ is 0.04 . This is not good system performance, because the pressure difference of interest, from the AOR to building $\left(\Delta P_{r b}\right)$, is small relative to the pressure difference from shaft to AOR $\left(\Delta P_{s r}\right)$. However, if the area ratio, $A_{r b} / A_{s r}$, is small, then the pressure ratio, $\Delta P_{r b} / \Delta P_{s r}$, is very large. For example if $A_{r b} / A_{s r}$ is 0.2 , then $\Delta P_{r b} / \Delta P_{s r}$ is 25 . This is much better for system performance, because the pressure difference of interest, $\Delta P_{r b}$, is relatively large. Thus, indirect pressurization is appropriate when $A_{r b} / A_{s r}$ is small as occurs when the area, $A_{s r}$, is relatively large. The area, $A_{s r}$, is often large for elevators with leaky doors, but it is generally not large for stairwells.

When an AOR is connected to an elevator, indirect pressurization can be considered. The performance of these systems is dependant on large flow areas around the elevator doors. These large areas mean that the pressure in the refuge area is almost the same as that in the shaft. This agrees with the analysis above. However, indirect pressurization should not be used when the area, $A_{s r}$, is relatively small as often occurs in stairwells. A direct pressurization system is suggested when $A_{s r}$ is relatively small.

\subsection{Systems to Deal with Fluctuations}

Smoke control systems should be able to maintain adequate pressurization under likely conditions of open doors, closed doors, broken windows and wind. Klote and Milke (1992) discuss approaches for stairwell pressurization and elevator smoke control to deal with pressure fluctuations due to the opening and closing of doors. The approaches are: pressure-relief venting, barometric damper venting, variable-supply air, and fire floor exhaust. It is believed that these approaches can be adapted for AOR, and this is done with a variable-supply air system in the example analysis. Application of these approaches to AOR are discussed below.

Pressure-Relief Venting This approach uses a vent to the outside and a "constant-supply" fan. The area of the vent is sized for operation of the smoke control system. The vent may be fitted with automatic dampers if it is desired for it to be normally closed. The vent must be large enough that the maximum pressure difference is not exceeded when all the doors are closed. When paths to the outside are open (doors and broken window), air flows through them and the pressure in the AOR drops. This system must maintain the minimum allowable pressure difference when a design number of doors and windows are open under design wind conditions.

Barometric Damper Venting This approach is similar to the one above, except that the vent has a barometric damper which closes when the pressure falls below a specified value. This minimizes air losses under the low pressure conditions.

Variable-Supply Air Variable-supply air can be achieved by using one of many fans commercially available for variable flow rate. Alternatively, a fan bypass arrangement of ducts and dampers can be used to vary the flow rate supplied to the shaft or to the AOR. The flow rate is controlled by static

${ }^{2}$ The supply rate is not actually constant, but varies to some extent with the pressure across the fan. For centrifugal fans this variation can be small. The term constant-supply is used here to differentiate this approach with that of using variable-supply air flow. 
pressure sensors located between the AOR and the building.

Fire Floor Exhaust Exhausting smoke from the fire floor can improve the pressure difference across the AOR doors on the fire floor. Upon detection of fire, the fire floor is exhausted. The detection system must be configured to identify the fire floor.

\section{Analysis of Smoke Control Systems}

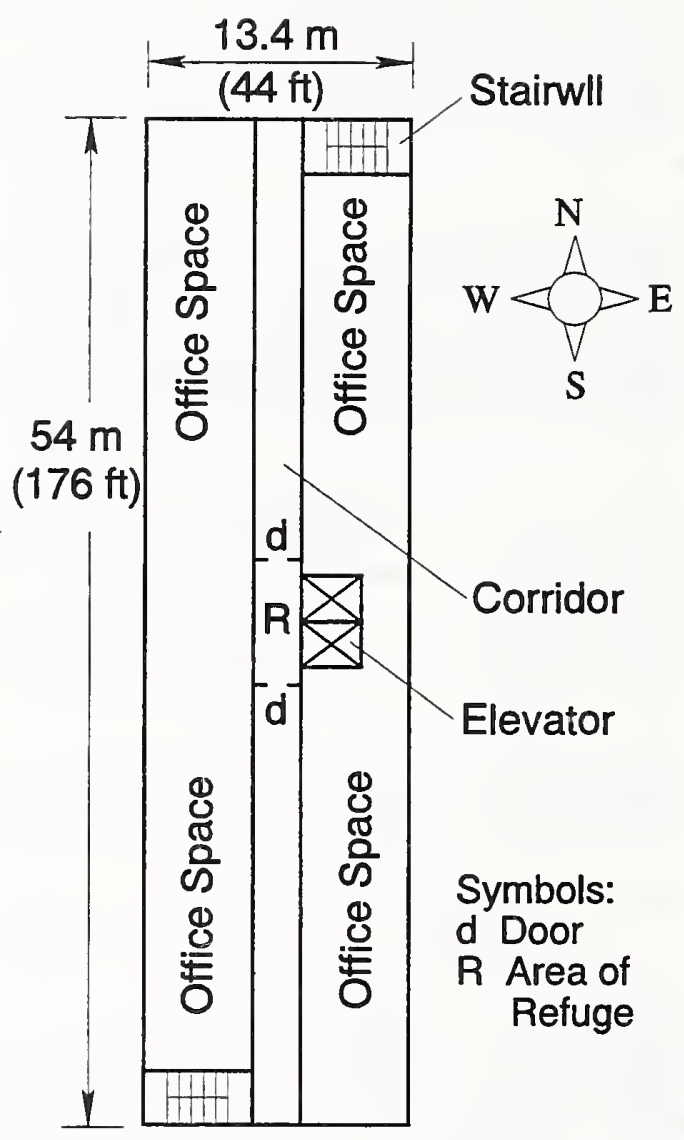

Smoke control systems can be analyzed by the computer program for analysis of smoke control systems (ASCOS) presented by Klote and Milke (1992). In this program, a building is represented by a network of spaces or nodes, each at a specific pressure and temperature. Shafts such as hoistways (elevator shafts) and stairwells are modeled by a series of vertical spaces, one for each floor. Air flows through openings from regions of high pressure to regions of low pressure.

In this model, air from the outside can be introduced by a pressurization system into any level of a shaft or even into other building spaces. This allows simulation of elevator smoke control systems. The

Figure 4 .

Building of example analysis of smoke control system for an area of refuge flows and leakage paths are considered to be at the mid-height of each level. The net air supplied by the HVAC system or by the pressurization system is considered constant and independent of pressure. The outside air temperature is considered constant. The program calculates the steady flows and pressures throughout the network, including the driving forces of wind, the pressurization system, and inside-to-outside temperature difference.

\section{Example Application}

The eleven-story building with the typical floor plan shown in figure 4 was selected arbitrarily for this example. The height between floors is $3.05 \mathrm{~m}(10 \mathrm{ft})$. The refuge areas are connected to an elevator and are indirectly pressurized by air injected into the second floor of the hoistway. The only smoke control system in this building is for the AOR. Unless multiple smoke control systems are designed to operate together, they are very likely to work against each other. If other smoke control systems are present, they must be included in the design analysis.

Most of the corridor doors are considered open, and so the pressure in the corridor and office space is nearly the same for a floor. In the ASCOS runs of this building, the building space on each floor is 
modeled as one node. The AOR on each floor is another node. The minimum and maximum allowable design pressure differences are 25 and $85 \mathrm{~Pa}\left(0.10\right.$ and 0.34 in $\left.\mathrm{H}_{2} \mathrm{O}\right)$. The design temperatures ${ }^{3}$ are listed in table 4.

General flow areas for this example are listed in table 5. These general flow areas were selected in an effort to be representative of those expected in the final building. Designers should arrive at such general flow areas using engineering judgement and data from various sources (such as Klote and Milke, and the ASHRAE Handbook of Fundamentals). However, flow areas in buildings vary over a wide range, and general values selected in this way have a high level of uncertainty. To account for this uncertainty, an approach using low and high leakage values (also in table 5) is used later in the analysis. Until noted all the flow areas are the general values.

This analysis considers that any vent that may exist at the top of the hoistway is tightly closed during smoke control operation. The presence of an open vent has a significant effect on such systems. If there is an open elevator vent during smoke control operation, this vent must be incorporated in the design analysis.

To minimize the effect of opening and closing doors, the exterior building doors and elevator doors on the ground floor are arbitrarily chosen to be open whenever the system is operating. Elevators are often recalled to the ground floor with open doors during fires, and exterior doors are often open for evacuation and firefighter entry. Thus this condition of doors seems realistic for many applications. For buildings with other conditions of elevator or exterior doors, those conditions need to be incorporated in the analysis for that building.

For this analysis, 21 runs $^{4}$ of the ASCOS program were made with the conditions of open doors, broken windows and wind as listed in table 6 . The flow rate of pressurization air and resulting pressure differences for the runs are listed in table 7 in SI units (table 8 in I-P units). These runs form a progression with conditions of later runs being based on what was learned from earlier runs. The following sections describe this progression which ends in determination of the flow rate of the supply fan and an approach for dealing with pressure fluctuations.

\subsection{No Broken Windows}

Runs 1 through 4 are for pressurization without a broken window and with the fire floor at the regular building temperature of $21^{\circ} \mathrm{C}\left(70^{\circ} \mathrm{F}\right)$. Any floor could be the fire floor. With all the doors closed to the AOR and the stairwells during summer (run 1), $4.48 \mathrm{~m}^{3} / \mathrm{s}(9,500 \mathrm{~cm}$ ) of supply air is required to produce the maximum allowable pressure difference, $85 \mathrm{~Pa}\left(0.34\right.$ in $\left.\mathrm{H}_{2} \mathrm{O}\right)$ across the AOR door at one floor. During winter it takes $4.39 \mathrm{~m}^{3} / \mathrm{s}(9,300 \mathrm{cfm})$ to produce similar pressurization (run 2).

The pressure differences in the above paragraph are considered positive when the flow is from the AOR

${ }^{3}$ For information about design temperatures see Klote and Milke (1992) and NFPA 92A (1988).

${ }^{4}$ In some cases, an ASCOS run listed in table 8 is the result of executing the program a number of times to determine the flow rate that is needed to obtain a desired pressure difference at a specific location. 
to the building. Unless otherwise noted, pressure differences in all discussions are across the AOR.

Runs 3 and 4 are with refuge area doors open on floors 2, 3 and with doors in both stairwells open on floors 1, 2, 3 and 4. The first floor stairwell door is to the outside. This group of open doors is used in these runs and several later runs to evaluate the effect of large openings from the pressurization system to the outside. Both runs were made at $4.39 \mathrm{~m}^{3} / \mathrm{s}(9,300 \mathrm{cfm})$ of pressurization air which is the same as run 2. As a result of the large openings, the pressure difference dropped to the range of 30 to $32 \mathrm{~Pa}(0.12$ to 0.13 in $\mathrm{H}_{2} \mathrm{O}$ ) in the summer (run 3 ) and 35 to $37 \mathrm{~Pa}\left(0.14\right.$ to $0.15 \mathrm{in}_{2} \mathrm{O}$ ) in the winter (run4).

For brevity, the position of the doors in runs 1 and 2 will be referred to as closed door condition, and the position of the doors in runs 3 and 4 will be referred to as opened door condition. If pressurization air were supplied at a constant rate of $4.39 \mathrm{~m}^{3} / \mathrm{s}(9,300 \mathrm{cfm})$, adequate pressurization would be maintained under conditions of closed doors and opened doors, provided that no windows open. Thus, a pressure-relief vent system can maintain acceptable pressure differences when there are no broken windows. However, later runs will show that this system is not capable of dealing with the pressure variations due to broken windows under conditions of wind.

\subsection{Broken Windows and No Wind}

The effects of a broken window without wind on the top floor (11th story) are examined in runs 5 through 8 . The top of the building was chosen for the broken window so that this would be a worst case for later runs with wind. This is a worst case with wind because wind velocity increases with elevation. For these runs and all other runs with a broken window, the temperature on the fire floor (floor 11) is $600^{\circ} \mathrm{C}\left(1110^{\circ} \mathrm{F}\right)$ as listed in table 4 . However, the effect of fire floor temperature on system performance is addressed later.

In order to maintain the maximum allowable pressure difference for the closed door condition, the pressurization flow rate must be reduced by $12 \%$ during the summer (run 5 ) and by $33 \%$ during the winter (run 6). Breaking the window, results in a fire floor pressure that is almost the same as the outside pressure. Thus the flow rate had to be reduced to prevent excessive pressure difference across the AOR on that floor.

The pressure levels of the opened door condition in summer (run 7) are similar to those without a broken window (run 3). However, the open door condition in winter (run 8) results in a pressure difference of $82 \mathrm{~Pa}\left(0.33\right.$ in $\left.\mathrm{H}_{2} \mathrm{O}\right)$ on floor 11 as compared to $27 \mathrm{~Pa}\left(0.11\right.$ in $\left.\mathrm{H}_{2} \mathrm{O}\right)$ in summer (run 7). Stack effect has a tendency to increase this pressure difference in winter. The main things that runs 5 through 8 show is that a broken window can result in increased pressure difference, or the flow must be decreased to prevent excessive pressure differences.

\subsection{Broken Windows, Wind and Closed Doors}

Runs 9 through 12 are for the building in the closed door configuration with a broken window on floor 11 , and these runs include wind effects. Runs 9 and 10 are for the broken window on the windward exposure, and runs 11 and 12 are for the broken window on the leeward exposure. 
For simplicity, this building has been selected so that the leakage of the north and south walls are negligible. Thus, wind effects need to be considered for only two exterior walls (east and west). It is observed from table 5 that the leakage of the east wall is the same as that of the west wall provided that neither has a broken window. The wind coefficients for these runs were taken from table 1 , and are 0.7 for the windward exposure and -0.4 for the leeward exposure. The design wind speed was $8.9 \mathrm{~m} / \mathrm{s}(20$ $\mathrm{mph})$ at a reference elevation of $10 \mathrm{~m}(33 \mathrm{ft})$ in suburban terrain $(n=0.28)$. The same design wind velocity, wind coefficients and wind exponent are used for later runs that incorporate wind effects. It can be seen that more pressurization air is needed to maintain the same pressure difference for a windward exposure (runs 9 and 10) than for a leeward exposure (runs 11 and 12).

\subsection{Broken Windows, Wind and Opened Doors}

As in the above section, these runs (13-16) have included wind effects with a broken window on floor 11 , but the building is in the opened door condition. The pressure differences at floor 11 are much lower when the broken window has a windward exposure (runs 13 and 14) than when it has a leeward exposure (runs 15 and 16). This is because pressure produced by wind blowing into the window reduces the pressure difference across the AOR doors. Windward exposure in the summer (run 13) is the worst case, resulting in only $2 \mathrm{~Pa}\left(0.01\right.$ in $\left.\mathrm{H}_{2} \mathrm{O}\right)$ across the AOR doors on floor 11 at $4.39 \mathrm{~m}^{3} / \mathrm{s}(9,300 \mathrm{cfm})$ of pressurization air. This is less than the minimum allowable pressure difference, and this indicates that an approach other than pressure-relief venting is needed for this building.

For run 16 , the pressure differences on most floors away from the fire are below the minimum pressure difference. As previously indicated, the minimum pressure difference only applies to the fire floor provided that the smoke control system is capable of specifically controlling the pressure difference at the fire floor. The variable-supply air system discussed above is one system that has this capability.

\subsection{Variable-Supply Air}

To maintain acceptable pressurization, the operation of a variable-supply air system is simulated in runs 17,18 and 19. The system set point is selected at $25 \mathrm{~Pa}\left(0.10\right.$ in $\left.\mathrm{H}_{2} \mathrm{O}\right)$ across the AOR door on the fire floor. The flow rate into the hoistway is controlled from a sensor on the fire floor to maintain this set point. For this example, the system is activated by a signal from a heat detector system that is zoned so that the fire floor can be identified. Other activation approaches are possible, and the reader is referred to Klote and Milke for a discussion of activation of smoke control systems. For these runs, floor 11 is considered the fire floor.

Run 17 is the same as run 2, except that the pressurization air is reduced by about $50 \%$ to maintain the above pressure difference. This flow rate $\left[2.22 \mathrm{~m}^{3} / \mathrm{s}(4,700 \mathrm{cfm})\right]$ is needed for the door closed condition without any broken windows.

Run 18 is the same as run 6, except the flow is again decreased in attempt to achieve the set point. Run 18 is for the closed door condition with a broken window without wind. However, a flow rate of 0.09 
$\mathrm{m}^{3} / \mathrm{s}(200 \mathrm{cfm})^{5}$ results in $32 \mathrm{~Pa}\left(0.13\right.$ in $\left.\mathrm{H}_{2} \mathrm{O}\right)$ on the fire floor. This is a little greater than the set point, but this pressure difference is acceptable.

Run 19 is the same as run 13 , except the flow rate was increased to $5.76 \mathrm{~m}^{3} / \mathrm{s}(12,200 \mathrm{cfm})$ to maintain the set point. This run is for the open door condition with a windward exposure for the broken window. The flow rate had to be increased by about $30 \%$ to maintain an acceptable pressure difference.

\subsection{Adjustment for Building Leakage}

Runs 20 and 21 are the same as run 19, except that low and high leakage flow areas (table 5) were used respectively. Low and high flow areas should be based on the engineering judgement and published data as the lowest and highest values that are considered acceptable construction for buildings being designed (or remodeled). However, some of the flow areas should not to be changed for the runs with low and high leakage. The areas of broken windows, opened doors, and leakage of elevator doors may be the same for all cases. The low leakage area building (run 20) requires about $14 \%$ less pressurization air than does the general leakage area building (run 19). The high leakage area building (run 21) requires about $14 \%$ more pressurization air.

\subsection{Adjustment for Building Leakage and Safety Factor}

A safety factor should be used to account for leakage paths not considered in the analysis and other factors that may effect system performance. The flow rate from run 21 was $6.56 \mathrm{~m}^{3} / \mathrm{s}(13,900 \mathrm{cfm})$. For a safety factor of $15 \%$, the pressurization supply fan would be sized at $7.54 \mathrm{~m}^{3} / \mathrm{s}(16,000 \mathrm{cfm})$. As previously stated, over-pressurization is prevented by using the variable-supply air approach with a set point of $25 \mathrm{~Pa}\left(0.10\right.$ in $\left.\mathrm{H}_{2} \mathrm{O}\right)$ across the AOR door on the fire floor.

\section{Effect of Fire Floor Temperature}

As previously stated, the runs with broken windows were made with a fire floor temperature of $600^{\circ} \mathrm{C}$ $\left(1110^{\circ} \mathrm{F}\right)$. To evaluate the effect of the fire floor temperature, all of these runs were recalculated with a fire floor temperature of $21^{\circ} \mathrm{C}\left(70^{\circ} \mathrm{F}\right)$. It may be surprising that the fire floor temperature had almost no effect on the pressure differences and flows throughout the building. The reason is that the dominating effect in these runs was the pressurization system. The pressure difference calculated by ASCOS is at the mid-height of each floor, and a minimum design pressure difference of $25 \mathrm{~Pa}\left(0.10\right.$ in $\left.\mathrm{H}_{2} \mathrm{O}\right)$ was selected so that pressurization forces dominate the buoyancy forces of the fire gases.

The fire floor temperature also has an effect on the mass flow through the broken window. Mass flow rate in ASCOS is calculated by a form of the orifice equation

${ }^{5}$ The flow rate of $0.09 \mathrm{~m}^{3} / \mathrm{s}(200 \mathrm{cfm})$ was selected to represent the leakage through tight control dampers. 


$$
m=C A \sqrt{2 \rho \Delta P}
$$

where:

$$
\begin{aligned}
& m=\text { mass flow rate, } \mathrm{kg} / \mathrm{s} \\
& C=\text { flow coefficient, dimensionless } \\
& A=\text { flow area }, \mathrm{m}^{2} \\
& \rho \quad=\text { density of gas in flow path } \\
& \Delta P=\text { pressure difference across flow path, } \mathrm{Pa}
\end{aligned}
$$

The units for these quantities are given only in SI units, because all internal calculations by ASCOS are in SI units. Because gas density decreases with increasing temperature, it can be seen from the above equation that the mass flow rate also decreases with increasing temperature. However, the flow also depends on the other paths in the building, as can be illustrated by the idea of effective flow area. When two paths in series have the same flow coefficients, the effective area of these paths is

$$
A_{e}=T_{e}^{1 / 2}\left(\frac{T_{1}}{A_{1}^{2}}+\frac{T_{2}}{A_{2}^{2}}\right)^{-1 / 2}
$$

where:

$A_{e}=$ effective flow area, $\mathrm{m}^{2}\left(\mathrm{ft}^{2}\right)$

$T_{e}=$ absolute temperature in effective path, $\mathrm{K}\left({ }^{\circ} \mathrm{R}\right)$

$T_{1}=$ absolute temperature in flow path $1, \mathrm{~K}\left({ }^{\circ} \mathrm{R}\right)$

$T_{2}=$ absolute temperature in flow path $2, \mathrm{~K}\left({ }^{\circ} \mathrm{R}\right)$

$A_{1}=$ area of flow path $1, \mathrm{~m}^{2}\left(\mathrm{ft}^{2}\right)$

$A_{2}=$ area of flow path $2, \mathrm{~m}^{2}\left(\mathrm{ft}^{2}\right)$

The value of the temperature, $T_{e}$, in the effective path is arbitrary, and it can be selected as either $T_{1}$ or $T_{2}$. For this example, the two paths in series are the broken window (path 1) and the leakage from the AOR to the building (path 2). Using $T_{e}=294 \mathrm{~K}\left(530^{\circ} \mathrm{R}\right), T_{1}=873 \mathrm{~K}\left(1570^{\circ} \mathrm{R}\right), T_{2}=294 \mathrm{~K}\left(530^{\circ} \mathrm{R}\right)$, $A_{1}=1.86 \mathrm{~m}^{2}\left(20.0 \mathrm{ft}^{2}\right), A_{2}=0.039 \mathrm{~m}^{2}\left(0.42 \mathrm{ft}^{2}\right)$; the effective flow area, $A_{e}$ is $0.038975 \mathrm{~m}^{2}(0.41952$ $\left.\mathrm{ft}^{2}\right)$. The reason for listing this area to so many places is apparent when calculations are made with the fire floor at the normal building temperature of $T_{1}=294 \mathrm{~K}\left(530^{\circ} \mathrm{R}\right)$, when $A_{e}$ is $0.038991 \mathrm{~m}^{2}(0.41967$ $\mathrm{ft}^{2}$ ). The high value of the floor temperature amounted to only a $0.04 \%$ decrease in the effective flow area. Because mass flow rate is directly proportional to the effective flow area, the high fire floor temperature results in a decrease of only $0.04 \%$ in the mass flow rate. For smoke control applications, this decrease is insignificant.

In this example the broken window is so large that the fire floor pressure is almost the same as the outside pressure, regardless of the fire floor temperature. The fire floor temperature has an insignificant effect on the pressure difference and mass flow across the AOR door. Thus, the fire floor temperature has no significant effect on the performance of the pressurization system, provided that the pressurization system maintains at least $25 \mathrm{~Pa}\left(0.10\right.$ in $\left.\mathrm{H}_{2} \mathrm{O}\right)$ across the doors of the areas of refuge. 


\section{Conclusions}

1. Feasibility: It is feasible to design smoke control systems for areas of refuge. The example calculation in this paper was for a specific pressurization system in a specific building, but many other systems are possible.

2. Opening and Closing Doors: The pressure fluctuations due to opening and closing building doors during fire situations can be significant, and the design of smoke control systems for areas of refuge need to address these pressure fluctuations.

3. Broken Windows: The pressure differences produced when windows break both with and without wind can be significant, and the design of smoke control systems for areas of refuge need to address these pressure differences.

4. Indirect Pressurization: A system that indirectly supplies air to the AOR thorough an elevator shaft can be designed to effectively control smoke. However, such indirect pressurization generally is not appropriate when the pressurization air is supplied through a stairwell.

5. Fire Temperature: The fire floor temperature has no significant effect on the performance of the pressurization system for an area of refuge, provided that the pressurization system maintains at least $25 \mathrm{~Pa}\left(0.10\right.$ in $\left.\mathrm{H}_{2} \mathrm{O}\right)$ across the doors of the areas of refuge.

6. Design Wind Data: Design wind data specifically for the design of smoke control systems are needed.

\section{References}

ASHRAE 1989. Chapter 24 Weather Data, Handbook of Fundamentals, American Society of Heating, Refrigerating and Air-Conditioning Engineers, Atlanta, GA.

Aynsley, R.M. 1989. The Estimation of Wind Pressures at Ventilation Inlets and Outlets on Buildings, ASHRAE Transactions, Vol 95, Part 2.

Bazjanac, V. 1974. Another Way Out? Progressive Architecture, April, pp 88-89.

Bazjanac, V. 1977. Simulation of Elevator Performance in High-Rise Buildings Under Conditions of Emergency, Human Response to Tall Buildings, Ed by D.J. Conway. Dowden, Hutchinson \& Ross, Stroudsburg, PA, pp 316-328.

Degenkolb, J. 1991. Elevator Usage During a Building Fire, ASME Symposium on Fire and Elevators, Baltimore, MD, February 19-20, 1991, American Society of Mechanical Engineers, New York, NY, pp 76-79.

Department of Justice. 1991. Nondiscrimination on the Basis of Disability by Public Accommodations and in Commercial Facilities; Americans with Disabilities Act 28 CFR Part 36, Final Rule, Federal Register, July 26. 
Fox C.C. 1991. Handicapped Use of Elevators, ASME Symposium on Fire and Elevators, Baltimore, MD, February 19-20, 1991, American Society of Mechanical Engineers, New York, NY, pp 80-82.

Gatfield, A.J. 1991. Elevators and Fire: Designing for Safety, ASME Symposium on Fire and Elevators, Baltimore, MD, February 19-20, 1991, American Society of Mechanical Engineers, New York, NY, pp 95-107.

Groner, N.E. and Levin, B.M. 1992. Human Factors Considerations in the Potential for Using Elevators in Building Emergency Evacuation Plans, National Institute of Standards and Technology, NIST-GCR-92-615.

Houghton, E.L. and Carruthers, N.B. 1976. Wind Forces on Buildings and Structures: an Introduction, Wiley, New York, NY.

Klote, J.H. and Milke, J.A. 1992. Design of Smoke Management Systems, American Society of Heating, Refrigerating and Air-Conditioning Engineers, Atlanta, GA.

Klote, J.H., Nelson, H.E., Deal, S., Levin, B.M. 1992. Staging Areas for Persons with Mobility Limitations, National Institute of Standards and Technology, NISTIR 4770.

Klote, J.H., Alvord, D.M., Levin, B.M., Groner, N.M. 1992. Feasibility and Design Considerations of Emergency Evacuation by Elevators, National Institute of Standards and Technology, NISTIR 4870.

Klote, J.H. 1988. An Analysis of the Influence of Piston Effect on Elevator Smoke Control, Nat. Bur. Stand. (U. S.), NBSIR 88-3751.

Kolousek, V., Pirner M., Fischer, O. and Naprstek, J. 1984. Wind Effects on Civil Engineering Structures, Elsevier, New York NY.

Levin, B.M. and Groner, N.E. 1992. Human Behavior Aspects of Staging Areas for Fire Safety in GSA Buildings, National Institute of Standards and Technology, NIST-GCR-92-606.

MacDonald, A.J. 1975. Wind Loading on Buildings, Wiley, New York NY.

NFPA 1988. Recommended Practice for Smoke Control Systems, NFPA 92A, Quincy, MA, National Fire Protection Assn.

NFPA 1991. Code for Safety to Life from Fire in Buildings and Structures, NFPA 101-1991, Quincy, MA, National Fire Protection Assn.

Pauls, J. 1988. People Movement, SFPE Handbook of Fire Protection Engineering, Society of Fire Protection Engineers, Boston, MA.

Pauls, J. 1977. Management and Movement of Building Occupants in Emergencies, DBR Paper No. 788, National Research Council, Ottawa, Canada.

Pauls, J., Gatfield A.J., Juillet, E. 1991. Elevator Use for Egress: The Human-Factors Problems and Prospects, ASME Symposium on Fire and Elevators, Baltimore, MD, February 19-20, 1991, American 
Pauls, J., Gatfield A.J., Juillet, E. 1991. Elevator Use for Egress: The Human-Factors Problems and Prospects, ASME Symposium on Fire and Elevators, Baltimore, MD, February 19-20, 1991, American Society of Mechanical Engineers, New York, NY, pp 63-75.

Sachs, P. 1978. Wind Forces in Engineering, 2nd Ed., Pergamon Press, New York.

Simiu, E. and Scanlan, R.H. 1986. Wind Effects on Structures, 2nd Ed., Wiley, New York, NY.

Table 3. The effect of elevation on wind velocity and wind pressure ${ }^{1}$

\begin{tabular}{|c|c|c|c|c|c|c|c|c|c|}
\hline \multirow{2}{*}{\multicolumn{2}{|c|}{$V_{o}$}} & \multicolumn{4}{|c|}{$z=35 \mathrm{~m}(115 \mathrm{ft})$} & \multicolumn{4}{|c|}{$z=100 \mathrm{~m}(330 \mathrm{ft})$} \\
\hline & & \multicolumn{2}{|c|}{$V$} & \multicolumn{2}{|c|}{$P_{w}$} & \multicolumn{2}{|c|}{$V$} & \multicolumn{2}{|c|}{$P_{w}$} \\
\hline $\mathrm{m} / \mathrm{s}$ & $\mathrm{mph}$ & $\mathrm{m} / \mathrm{s}$ & $\mathrm{mph}$ & $\mathrm{Pa}$ & in $\mathrm{H}_{2} \mathrm{O}$ & $\mathrm{m} / \mathrm{s}$ & $\mathrm{mph}$ & $\mathrm{Pa}$ & in $\mathrm{H}_{2} \mathrm{O}$ \\
\hline 7 & 16 & 10 & 22 & 48 & 0.19 & 13 & 29 & 81 & 0.33 \\
\hline 9 & 20 & 13 & 29 & 81 & 0.33 & 17 & 38 & 140 & 0.56 \\
\hline 11 & 25 & 16 & 36 & 120 & 0.48 & 21 & 47 & 210 & 0.84 \\
\hline
\end{tabular}

${ }^{1}$ Wind pressure and velocity calculated from equations (3) and (4) using $z_{o}$ of $10 \mathrm{~m}(33 \mathrm{ft}), C_{w}$ of 0.8 and $n$ of 0.28 .

Table 4. Design temperatures for analysis of example smoke control system

\begin{tabular}{|lrr|}
\hline & ${ }^{\circ} \mathrm{C}$ & ${ }^{\circ} \mathrm{F}$ \\
\hline Building temperature & 21 & 70 \\
Fire floor temperature & 600 & 1110 \\
Winter outside temperature & -15 & 5 \\
Summer outside temperature & 32 & 90 \\
\hline
\end{tabular}


Table 5. Flow areas for analysis of example smoke control system*

\begin{tabular}{|lccccccc|}
\hline \multicolumn{1}{c}{\begin{tabular}{c} 
General Values \\
\multicolumn{1}{|c}{ Location }
\end{tabular}} & \multicolumn{2}{c}{ Low Leakage ${ }^{* *}$} & \multicolumn{2}{c}{ High Leakage ${ }^{* *}$} \\
\hline $\begin{array}{l}\text { First floor exterior East wall } \\
\text { (exterior doors opened) }\end{array}$ & 0.975 & 10.5 & $\mathrm{NC}$ & $\mathrm{NC}$ & $\mathrm{NC}$ & $\mathrm{NC}$ \\
$\begin{array}{l}\text { First floor exterior West wall } \\
\text { (exterior doors opened) }\end{array}$ & 0.975 & 10.5 & $\mathrm{NC}$ & $\mathrm{NC}$ & $\mathrm{NC}$ & $\mathrm{NC}$ \\
$\begin{array}{l}\text { Exterior East walls above 1st floor } \\
\text { (no broken window) }\end{array}$ & 0.0204 & 0.220 & 0.0139 & 0.150 & 0.0855 & 0.0920 \\
$\begin{array}{l}\text { Exterior East walls above 1st floor } \\
\text { (with broken window) }\end{array}$ & 1.86 & 20.0 & $\mathrm{NC}$ & $\mathrm{NC}$ & $\mathrm{NC}$ & $\mathrm{NC}$ \\
$\begin{array}{l}\text { Exterior West walls above 1st floor } \\
\text { (no broken window) }\end{array}$ & 0.0204 & 0.220 & 0.00929 & 0.100 & 0.0855 & 0.0920 \\
$\begin{array}{l}\text { Exterior West walls above 1st floor } \\
\text { (with broken window) }\end{array}$ & 1.86 & 20.0 & $\mathrm{NC}$ & $\mathrm{NC}$ & $\mathrm{NC}$ & $\mathrm{NC}$ \\
$\begin{array}{l}\text { Stairwell to building (stair door } \\
\text { closed) }\end{array}$ & 0.0251 & 0.270 & 0.00929 & 0.100 & 0.0279 & 0.300 \\
$\begin{array}{l}\text { Stairwell to building (stair door } \\
\text { opened) }\end{array}$ & 0.975 & & & & & & \\
$\begin{array}{l}\text { Building floor } \\
\text { Building to AOR (AOR doors }\end{array}$ & 0.0204 & 0.220 & 0.00465 & 0.0500 & 0.121 & 1.30 \\
closed) & 0.0390 & 0.42 & 0.0186 & 0.200 & 0.0557 & 0.600 \\
$\begin{array}{l}\text { Building to AOR (AOR doors } \\
\text { opened) }\end{array}$ & 2.04 & 22.0 & $\mathrm{NC}$ & $\mathrm{NC}$ & $\mathrm{NC}$ & $\mathrm{NC}$ \\
$\begin{array}{l}\text { AOR to hoistway (elevator door } \\
\text { closed) }\end{array}$ & 0.149 & 1.60 & $\mathrm{NC}$ & $\mathrm{NC}$ & $\mathrm{NC}$ & $\mathrm{NC}$ \\
$\begin{array}{l}\text { AOR to hoistway (elevator door } \\
\text { opened) }\end{array}$ & 0.743 & 8.00 & $\mathrm{NC}$ & $\mathrm{NC}$ & $\mathrm{NC}$ & $\mathrm{NC}$ \\
\hline
\end{tabular}

*Areas are listed to three significant figures calculations and for conversion between unit systems. However, this should not be taken an indication of accuracy, because these areas can only be roughly estimated.

${ }^{* *} \mathrm{NC}$ indicates no change from the general values. 
Table 6. Arrangement of doors and wind conditions for example analysis

\begin{tabular}{|c|c|c|c|c|c|c|c|c|}
\hline Run & Season & $\begin{array}{c}\text { AOR Doors } \\
\text { Open on Floors } \\
\end{array}$ & $\begin{array}{c}\text { Stairwell } \\
\text { Doors Open } \\
\text { on Floors }^{2}\end{array}$ & $\begin{array}{c}\text { Broken } \\
\text { Window } \\
\text { on Floors }\end{array}$ & $\begin{array}{l}\text { Wind } \\
\mathrm{m} / \mathrm{s}\end{array}$ & $\mathrm{mph}$ & $\begin{array}{c}\text { Wind } \\
\text { Direction }^{3}\end{array}$ & $\begin{array}{l}\text { Building } \\
\text { Leakage }^{4}\end{array}$ \\
\hline 1 & Summer & None & None & None & 0 & 0 & NA & General \\
\hline 2 & Winter & None & None & None & 0 & 0 & NA & General \\
\hline 3 & Summer & $2,3,4$ & $1,2,3,4$ & None & 0 & 0 & NA & General \\
\hline 4 & Winter & $2,3,4$ & $1,2,3,4$ & None & 0 & 0 & NA & General \\
\hline 5 & Summer & None & None & 11 & 0 & 0 & NA & General \\
\hline 6 & Winter & None & None & 11 & 0 & 0 & NA & General \\
\hline 7 & Summer & $2,3,4$ & $1,2,3,4$ & 11 & 0 & 0 & NA & General \\
\hline 8 & Winter & $2,3,4$ & $1,2,3,4$ & 11 & 0 & 0 & $\mathrm{NA}$ & General \\
\hline 9 & Summer & None & None & 11 & 8.9 & 20 & + & General \\
\hline 10 & Winter & None & None & 11 & 8.9 & 20 & + & General \\
\hline 11 & Summer & None & None & 11 & 8.9 & 20 & - & General \\
\hline 12 & Winter & None & None & 11 & 8.9 & 20 & - & General \\
\hline 13 & Summer & $2,3,4$ & $1,2,3,4$ & 11 & 8.9 & 20 & + & General \\
\hline 14 & Winter & $2,3,4$ & $1,2,3,4$ & 11 & 8.9 & 20 & + & General \\
\hline 15 & Summer & $2,3,4$ & $1,2,3,4$ & 11 & 8.9 & 20 & - & General \\
\hline 16 & Winter & $2,3,4$ & $1,2,3,4$ & 11 & 8.9 & 20 & - & General \\
\hline 17 & Winter & None & None & None & 0 & 0 & NA & General \\
\hline 18 & Winter & None & None & 11 & 0 & 0 & NA & General \\
\hline 19 & Summer & $2,3,4$ & $1,2,3,4$ & 11 & 8.9 & 20 & + & General \\
\hline 20 & Summer & $2,3,4$ & $1,2,3,4$ & 11 & 8.9 & 20 & + & Low \\
\hline 21 & Summer & $2,3,4$ & $1,2,3,4$ & 11 & 8.9 & 20 & + & High \\
\hline
\end{tabular}

${ }^{1}$ On floors were AOR doors are open, the doors on both sides of the AOR are open.

$21,2,3,4$ indicates that, for both stairwells, the first floor exterior door and the interior doors on floors 2,3 and 4 are open.

${ }^{3} \mathrm{NA}$ indicates not applicable; + indicates that the wind is towards (or into) the broken window; - indicates the wind is away from the broken window.

${ }^{4}$ Flow areas for low, general and high leakage are listed in tables 3, 4 and 5. 
Table 7. Computer-calculated pressure differences for smoke control example in SI units

\begin{tabular}{|c|c|c|c|c|c|c|c|c|c|c|c|}
\hline Run & $\begin{array}{l}\text { Flow } \\
\text { Rate } \\
\mathrm{m}^{3} / \mathrm{s}\end{array}$ & Pressur & liffereno & pasca & $\mathrm{m} \mathrm{A}$ & bui & n flo & 8 & 9 & 10 & 11 \\
\hline 1 & 4.48 & 85 & 82 & 82 & 82 & 82 & 82 & 82 & 82 & 82 & 82 \\
\hline 2 & 4.39 & 85 & 85 & 85 & 85 & 85 & 85 & 85 & 85 & 85 & 85 \\
\hline 3 & 4.39 & Open & Open & Open & 32 & 30 & 30 & 30 & 30 & 30 & 30 \\
\hline 4 & 4.39 & Open & Open & Open & 35 & 35 & 35 & 35 & 35 & 37 & 37 \\
\hline 5 & 3.87 & 65 & 62 & 62 & 62 & 62 & 62 & 62 & 62 & 65 & 85 \\
\hline 6 & 2.93 & 37 & 37 & 37 & 37 & 40 & 40 & 40 & 40 & 45 & 85 \\
\hline 7 & 4.39 & Open & Open & Open & 32 & 30 & 30 & 30 & 30 & 30 & 27 \\
\hline 8 & 4.39 & Open & Open & Open & 32 & 32 & 32 & 35 & 35 & 40 & 82 \\
\hline 9 & 4.39 & 82 & 80 & 80 & 80 & 80 & 80 & 80 & 80 & 80 & 82 \\
\hline 10 & 3.82 & 65 & 65 & 62 & 65 & 65 & 65 & 65 & 65 & 67 & 85 \\
\hline 11 & 3.02 & 37 & 35 & 35 & 32 & 32 & 32 & 32 & 32 & 35 & 85 \\
\hline 12 & 1.32 & 5 & 5 & 7 & 7 & 7 & 7 & 7 & 7 & 12 & 85 \\
\hline 13 & 4.39 & Open & Open & Open & 32 & 30 & 30 & 30 & 27 & 25 & 2 \\
\hline 14 & 4.39 & Open & Open & Open & 32 & 32 & 32 & 32 & 35 & 35 & 42 \\
\hline 15 & 4.39 & Open & Open & Open & 27 & 27 & 25 & 25 & 27 & 30 & 62 \\
\hline 16 & 1.51 & Open & Open & Open & 2 & 2 & 2 & 5 & 5 & 10 & 85 \\
\hline 17 & 2.22 & 22 & 22 & 22 & 25 & 25 & 25 & 25 & 25 & 25 & 25 \\
\hline 18 & 0.09 & 2 & 0 & 0 & 2 & 5 & 5 & 5 & 7 & 10 & 32 \\
\hline 19 & 5.76 & Open & Open & Open & 55 & 52 & 50 & 50 & 50 & 45 & 25 \\
\hline 20 & 4.96 & Open & Open & Open & 55 & 52 & 50 & 50 & 47 & 47 & 25 \\
\hline 21 & 6.56 & Open & Open & Open & 57 & 55 & 52 & 52 & 50 & 47 & 25 \\
\hline
\end{tabular}


Table 8. Computer-calculated pressure differences for smoke control example in I-P units

\begin{tabular}{|c|c|c|c|c|c|c|c|c|c|c|c|}
\hline \multirow[b]{2}{*}{ Run } & \multirow{2}{*}{$\begin{array}{l}\text { Flow } \\
\text { Rate } \\
\text { cfm }\end{array}$} & \multicolumn{10}{|c|}{ Pressure difference in inches of $\mathrm{H}_{2} \mathrm{O}$ from AOR to building on floors: } \\
\hline & & 2 & 3 & 4 & 5 & 6 & 7 & 8 & 9 & 10 & 11 \\
\hline 1 & 9,500 & 0.34 & 0.33 & 0.33 & 0.33 & 0.33 & 0.33 & 0.33 & 0.33 & 0.33 & 0.33 \\
\hline 2 & 9,300 & 0.34 & 0.34 & 0.34 & 0.34 & 0.34 & 0.34 & 0.34 & 0.34 & 0.34 & 0.34 \\
\hline 3 & 9,300 & Open & Open & Open & 0.13 & 0.12 & 0.12 & 0.12 & 0.12 & 0.12 & 0.12 \\
\hline 4 & 9,300 & Open & Open & Open & 0.14 & 0.14 & 0.14 & 0.14 & 0.14 & 0.15 & 0.15 \\
\hline 5 & 8,200 & 0.26 & 0.25 & 0.25 & 0.25 & 0.25 & 0.25 & 0.25 & 0.25 & 0.26 & 0.34 \\
\hline 6 & 6,200 & 0.15 & 0.15 & 0.15 & 0.15 & 0.16 & 0.16 & 0.16 & 0.16 & 0.18 & 0.34 \\
\hline 7 & 9,300 & Open & Open & Open & 0.13 & 0.12 & 0.12 & 0.12 & 0.12 & 0.12 & 0.11 \\
\hline 8 & 9,300 & Open & Open & Open & 0.13 & 0.13 & 0.13 & 0.14 & 0.14 & 0.16 & 0.33 \\
\hline 9 & 9,300 & 0.33 & 0.32 & 0.32 & 0.32 & 0.32 & 0.32 & 0.32 & 0.32 & 0.32 & 0.33 \\
\hline 10 & 8,100 & 0.26 & 0.26 & 0.25 & 0.26 & 0.26 & 0.26 & 0.26 & 0.26 & 0.27 & 0.34 \\
\hline 11 & 6,400 & 0.15 & 0.14 & 0.14 & 0.13 & 0.13 & 0.13 & 0.13 & 0.13 & 0.14 & 0.34 \\
\hline 12 & 2,800 & 0.02 & 0.02 & 0.03 & 0.03 & 0.03 & 0.03 & 0.03 & 0.03 & 0.05 & 0.34 \\
\hline 13 & 9,300 & Open & Open & Open & 0.13 & 0.12 & 0.12 & 0.12 & 0.11 & 0.10 & 0.01 \\
\hline 14 & 9,300 & Open & Open & Open & 0.13 & 0.13 & 0.13 & 0.13 & 0.14 & 0.14 & 0.17 \\
\hline 15 & 9,300 & Open & Open & Open & 0.11 & 0.11 & 0.10 & 0.10 & 0.11 & 0.12 & 0.25 \\
\hline 16 & 3,200 & Open & Open & Open & 0.01 & 0.01 & 0.01 & 0.02 & 0.02 & 0.04 & 0.34 \\
\hline 17 & 4,700 & 0.09 & 0.09 & 0.09 & 0.10 & 0.10 & 0.10 & 0.10 & 0.10 & 0.10 & 0.10 \\
\hline 18 & 200 & 0.01 & 0.01 & 0.00 & 0.01 & 0.02 & 0.02 & 0.02 & 0.03 & 0.04 & 0.13 \\
\hline 19 & 12,200 & Open & Open & Open & 0.22 & 0.21 & 0.20 & 0.20 & 0.20 & 0.18 & 0.10 \\
\hline 20 & 10,500 & Open & Open & Open & 0.22 & 0.21 & 0.20 & 0.20 & 0.19 & 0.19 & 0.10 \\
\hline 21 & 13,900 & Open & Open & Open & 0.23 & 0.22 & 0.21 & 0.21 & 0.20 & 0.19 & 0.10 \\
\hline
\end{tabular}



